\title{
Economic Activities and Agency of "Love-Driven" International Migrants in the City of Zagreb
}

DOI $10.17234 / 9789531756525.11$

Jasna Čapo

Institute of Ethnology and Folklore Research

Šubićeva 42, 10000 Zagreb, Croatia

capo@ief.hr

The chapter targets a specific population of foreign nationals in the capital city of Zagreb: well educated, highly skilled, young and middle aged immigrants of both sexes, from all over the world, who have been driven to the city by love/partnership. Based on encounters and interviews with such persons, as well as an analysis of foreign immigrants' Facebook pages, it analyses systemic constraints on migrants' agency and entrepreneurship.

Keywords: international skilled migration, love-driven migrants, agency, entrepreneurship, Zagreb

"I feel Croatia is like a relationship: there is that one guy you really liked but you knew he had way too many issues. You knew, I can't carry that baggage. If I step into this, I'm on this upper trajectory, and that guy is going to bring me down." (M., February 2016, excerpt from an interview)

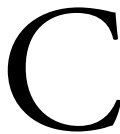

roatia has traditionally been an emigration country. Though to this day it remains one - emigration being on the rise in the current decade (see Župarić-Iljić 2016 for an assessment) - this chapter is about foreign nationals who immigrate to Croatia. It targets a specific population of foreign nationals in the capital city of Zagreb: well-educated, highly skilled, young and middle aged immigrants of both sexes, from all over the world, for whom economic and financial considerations are not primary driving motivations for migration. Their most common reason of arrival is partnership with a Croatian person, hence the name proposed for this mobility: love-driven mobility. The chapter, which analyses migrants' agency and entrepreneurship in Zagreb, is based on encounters and interviews with such persons as well as an analysis of foreign immigrants' Facebook pages.

The research has been conducted within the framework of the project "Citymaking: space, culture and identity". ${ }^{1}$ The project focuses on the transformations

1 The project is funded by the Croatian Science Foundation, 2014-2018, project no. 2350. The presentation of the project draws from the project proposal, see www.citymaking.eu. 
and restructuring currently taking place in the Croatian capital, Zagreb. A research hypothesis is that city-making in Zagreb is a result of a set of intertwined variables (political, economic, social and cultural) intersecting at different levels (from local and national to European and global). The project revolves around the issue of agency, in which it pays attention to three actors of city-making: urban dwellers, civil society and city managers (policy makers). One of its aspects deals specifically with mobility as a vector of diversification of city population and of transformations of the city itself. Though, at the moment, immigration of foreign nationals to Zagreb and Croatia is still negligible, we deem it important to study these processes even at this early stage. They indicate motives for migration, constraints on migrants' settlement and life in the city, as well as their role in transformations of the city. Anticipating changes that might be brought by immigration has proven timely since, mainly due to short-term tourist mobilities, Zagreb has become a changing city-scape in the last few years and, as such, is attracting more foreign national immigrants. In presenting a section of immigrants in the city - young, skilled, cosmopolitan - I discuss the constraints imposed by local and national economic structures on their agency and entrepreneurship.

The chapter begins with a presentation of statistics regarding immigration to Zagreb and Croatia. Then it situates the research in the context of contemporary international mobility and theories used to make sense of them. The third section presents the data, while the ensuing one deals with migrants' efforts at making a living and establishing themselves in Zagreb. The last one winds up with conclusions on the relationship of agency and structural constraints that determine migrants' lives in the city.

\section{Incipient international migration to Zagreb and Croatia}

Though immigration to Croatia is still small in numbers, it is estimated to have been on the rise since 2011. It is mostly generated by nationals of the European Economic Area and Bosnia and Herzegovina and by remigration flows from Croatian diaspora (Župarić-Iljić 2016). The census data for Zagreb in 2011 clearly show this: almost two thirds of immigrants come from former Yugoslav republics (half of which from Bosnia and Herzegovina) and about a third from other countries, among which Germany takes up almost half (because of Croatian remigrants from that country). Percentage-wise, about $6 \%(48,800)$ of the entire population of Zagreb $(790,017)$ have immigrated from countries other than former Yugoslav republics, and of those almost half have come from Germany $(22,984)$. The figures on the number of persons with Croatian and another citizenship $(15,586)$ and with only foreign citizenship $(4,871)$ living in Zagreb confirm that Croatians living abroad are providing the biggest contingent of international immigrants 
(Grad Zagreb 2014, own calculations). The specifics of return and relocation of Croatians living abroad to Croatia have been studied, albeit not to a satisfying degree (Peračković 2006; Čapo et al. 2014).

Other-than-Croatian immigrants to the country have, with the exception of asylum seekers (Pozniak and Petrović 2014; Čapo 2015; Jurković and Rajković Iveta 2016), received even less attention. A study about the transnational activities of Chinese migrants in Croatia was carried out in 2009/2010 (Kuti and Božić 2011). An initial exploratory study, which analysed a class-specific group of immigrants labourers with work permits - brought to light that of 1,518 foreigners registered as workers in mid-2011, about $90 \%$ were employed in construction and shipyard industries. A convenient sample of foreign workers further showed that more than 90\% were from Bosnia and Herzegovina and exhibited characteristics typical for a workers' immigrant population: they were predominantly males, aged between 30 and 50 years, with low levels of qualifications and employed on annual contracts (Božić et al. 2013).

This chapter targets a different population of foreign nationals in Zagreb: welleducated and highly skilled immigrants from all over the world who do not come on labour permits to work in industrial sectors but who move either driven by love or, to a lesser extent, by business projects.

\section{Pluralisation of migration studies}

Migration studies are today more heterogeneous and complex than ever, in terms of topics researched as well as theoretical and methodological approaches.

Classical topics such as economic and labour migrations, which used to dominate research, have been broadened by studies of asylum seekers and refugee migrations (see e.g. a seminal study by Mallki 1995), and, in the context of the demise of socialist (communist) multinational states such as the Soviet Union and Yugoslavia, by related research into so called (co-)ethnic or ethnically privileged migrations of ethnic minorities toward their "mother countries" (see e.g. Münz and Ohliger 1997; in the Croatian context: Čapo Žmegač 2005; Čapo Žmegač et al. 2010). Return migrations of diasporans and refugees around the world has been another developing field (Cassarino 2004; Markowitz and Stefansson 2004; Tsuda 2009; Čapo Žmegač 2010; King et al. 2011; Čapo 2012). What all of these studies have in common is that they primarily deal with (re)migrants at the lower ends of social stratification.

More recent are studies of migrations at the other end of social stratification. Migrations of corporate managers, financial elites, employees of international organizations, travelling IT specialists, whether classified as "expatriates", "(highly) 
skilled migrants", "transnational elites", "transnational capitalist class", "transnational/migrant professionals" and represented as the paradigmatic drivers of globalization, have become a well-established field of migration studies (among other, see Meier 2015; Fechter 2007; Nowicka 2006; Beaverstock 2005; Sklair 2001 in Favell et al. 2009).

To bridge the gap between the research in low-level (labour) and upper level (elite) migrations, researchers have advocated a focus on "middling" positions (Favell et al. 2009; Conradson and Latham 2005) or migrations by individuals from the middle classes of the society: "students, nurses, mid-level technical and clerical employees, ambitious or adventurous upwardly mobile middle-classes, migrants from a range of intermediate developing states, and many more it would be hard to describe as 'elites'" (Favell et al. 2009: 2). Vered Amit's collection of articles presenting "different types of voyaging" (Amit 2007: 2), all of which feature certain privileges (stemming from the resources of "money, time and credentials" and "relative affluence" or "modest prosperity", ibid.) is another example of this strand of research. It not only fills in the gap between studies of elite and lower-classes' migrations but also reflects broader developments in the global mobility of middle classes and expansion of varieties of travel (ibid.; Favell et al. 2009).

Lifestyle migrants, or "relatively affluent individuals of all ages, moving either part-time or full-time to places that, for various reasons, signify, for the migrants, a better quality of life" (Benson and O'Reilly 2009: 609) are a "middling" group that has captured the interest of researchers and become a flourishing sub-field of migration studies. Since, in this form of migration, migrants "do not move to pursue place-dependent opportunities for work" but to be "in a place somehow personally meaningful that they believe will fulfil a "lifestyle commitment", this strand of research is known as non-economic or amenity migrations in the US (Hoey 2014: 71-72).

New terrains of migration research have been matched by a wide range of new and ever increasing diversification of research questions. They put aside the hitherto dominant interest in (labour) migrants' integration and assimilation in the receiving societies. Migrations have been analysed with respect to theories of globalisation (Sassen 1998; Castells 2000) and transnationalisation (Glick Schiller et al. 1992; Pries 2001; Levitt and Glick Schiller 2004). The first have evolved toward theories of unbound mobilities and motility (Sheller and Urry 2006; Hannam et al. 2006); the latter have, among other, grounded transnational processes in locality (Smith and Guarnizo 1998), focused on transnational social spaces and identities (Faist 2000; Levitt 2001), related migration to processes of urban rescaling (Glick Schiller and Çağlar 2009, 2011), etc. Within this pluralization of approaches, Boris Nieswand (2016) identified a trend towards the "decentering of migration studies", whereby researchers focus less exclusively on migrants and more on mainstream social actors 
and institutions: nation-states, cities, social fields, diasporas etc. "Decentring" also means that migration studies are opening up to broader social and cultural issues and research. Moving away from migration per se to studying its consequences in a broader societal context is seen as an enrichment of migration topics on the one hand, and a mode of integrating migration research paradigms in general sociological approaches on the other.

The "case" of international migrants to the city of Zagreb analysed here is "symptomatic of the increasing diversity of contemporary patterns of international migration" (Conradson and Latham 2005: 288). These non-economic migrants landed in Zagreb due primarily to an intimate relationship with a Croatian partner. They fit squarely into contemporary patterns of international mobility in the sense that at the root of their arrival is middle classes' mobility: partners met on the occasion of longer sojourns or while traveling abroad, whether in the capacity of corporate executives, freelance industrial designers or other professionals, students or tourists. Some of the Croatian partners are so-called second generation Croatians (descendants of Croatian migrants abroad) who were born and raised outside of Croatia. Following a "fatal" encounter, possibly in the context of a life transition, specific family circumstances or readiness to move on to another country, couples made the decision to settle in the country from which one of the partners originates. What also makes them akin to middling forms of contemporary migrations is their qualifications, relative freedom to move and complex mobility trajectories.

Love-driven migration may be considered a form of family migration. However, I suggest it is very different from, for example, the well-known case of family migrations for the purpose of family reunification that followed the stop on recruitment of labour migrants in Western Europe in the 1970s and 1980s. The spatial, economic, and social context as well as time frame are very different in the case analysed here: these are migrations to a partner's/spouse's country of origin in the context of middle class and skilled mobility, previous multiple periods of travelling and sojourning in different countries by both partners. Moreover, the Croatian partner may also engage in migration, or, more precisely remigration, if $s /$ he was living outside of the country and is now settling in Croatia with a foreign partner.

The chapter reconsiders the assumption that transnational migrants are actors of restructuring, reinventing and repositioning of the cities in which they settle (Glick Schiller and Çağlar 2009, 2011). It explores the extent to which these welleducated, highly-skilled, middle class, love-driven migrants are engaging with the city of Zagreb and changing its face. In what ways are they contributing to reimagining the city? What are the limits to their involvement and agency? In particular, can they fully utilise the human capital they bring with and rescale Zagreb with respect to other cities (ibid.)? The interpretation draws on theoretical discussions on the relationship between individual agency and structure proposed in socio- 
logical literature on individualisation and late modernity (Giddens 1991; Bauman 2000; Beck and Beck-Gernsheim 2001) and revisited in the discussions of life-style migrations (Korpela 2014; Benson and Osbaldiston 2016). I suggest that migrants' agency in the city of Zagreb is constrained and unable to fully develop because of systemic limits to entrepreneurship, in particular to foreign entrepreneurship. This is, however, not peculiar to Zagreb but applies to all of Croatia.

\section{Mobile and middle class backgrounds of love-driven migrants in Zagreb}

The data have been gathered using a variety of methods: extensive semi-structured interviews, informal conversations and meetings in public and private settings with twelve international migrants in Zagreb, as well as by attending foreigners' meet-ups and visiting their business establishments. ${ }^{2}$ The ethnographic fieldwork has been backed by analyses of several of Facebook pages created by foreign nationals (Expats in Zagreb, Internationals living in Croatia) ${ }^{3}$ and portals aiming at the population of foreign nationals in Zagreb like Unique Zagreb ${ }^{4}$. Continuous following of Facebook activities, linked with a detailed analysis of posts between May and September 2016 and in February 2017 yielded more general information about international migrants in Zagreb, in particular their reasons for settling, businesses and ways of socializing, while interview materials provided detailed and contextualised insights into their lives, aspirations, and constraints on their agency.

Facebook posts reveal that the dominant cause of foreign nationals' arrival to Zagreb and Croatia is partnership with a Croatian wo/man, usually a person with a migration history herself/himself. 5 This was confirmed by my interlocutors. Like the foreign national partner, the Croatian partner has usually had quite a mobile life trajectory and the couple have decided to live in Croatia either because of the spouse's wish to remigrate or related to a family matter (illness or death of a parent). Such relationships unite partners from distant countries. For example, one partner-

2 In addition I have talked to three diplomats; their views are only partially referred to.

3 Internationals living in Croatia is a rather small Facebook community of people spread over Croatia, with about 800 members. On the contrary, FB group Expats in Zagreb, has a growing membership: almost 1,900 persons in March 2017. One should note that not all group members are foreigners living in Zagreb and Croatia; some are planning to relocate, some are locals with international experience (some of whom are spouses of foreign immigrants), some are probably just locals who like to hang around international audiences.

4 This web page is managed by the same person who administers the FB group Expats in Zagreb.

5 Diplomats, whose arrival to Zagreb had different grounds, are not very actively engaged in these FB pages. They have their own networking channels, and diplomats' spouses manage an own association and FB group - International Women's Club Zagreb. 
ship connected a French citizen with roots in Ivory Coast and Martinique with a Croatian; the couple met in San Francisco. Another was formed by a Venezuelan living in Germany and a Croatian, born and raised in Germany, one by a Sri Lankan and a Croatian who met at an international event abroad, a Jamaican who met their Croatian spouse during their career in an international organisation, etc. Of all interview partners, only a couple from Ukraine had no romantic reason for coming to Croatia; they chose to relocate to Zagreb with an intention to open a restaurant business. Croatia was chosen not because it offered any business advantages, but because previous tourist visits made them "fall in love" with it.

In three cases, the relationship which was the cause of migration fell apart, but in spite of such an outcome, the former international partner stayed in Zagreb. The reasons that these persons gave for remaining after separation from a local partner were the following: they either thought Zagreb was "a beautiful city", or liked its "way of life", saw a "potential" in living in Zagreb, or, for some personal reason found it alright to remain and see how life goes on. Three persons left Croatia since the interviews were conducted, either because of economic (inability to sustain oneself) or family reasons.

Out of two women and ten men, all but two were in their late twenties or thirties at the time of arrival. At the time of the interviews, held between February and March 2016 and January and March 2017, they were between 22 and 62 of age. The duration of their stay in Zagreb has been between eight months and six years. Three interview partners are of African descent, two are Asians.

The interviewees have multi-racial, multi-ethnic and/or multi-cultural backgrounds. Some hold double citizenship, of an EU and non-EU state (e.g. a South African and Grenadian also have British citizenship, one person has Ivory Coast and French citizenship, another one Egyptian and Bosnian etc.). Immigrants have obtained residence permits via family reunification provisions, work permits, or based on the citizenship of Croatia or another EU country. One person lived in Zagreb for two years "under the radar", without a residence permit.

Throughout their lives, these individuals have been exceptionally mobile, frequently changing residence or traveling as tourists. Due to their mobility before coming to Croatia, they have forged multi-focal transnational social spaces (cf. Kuti and Božić 2011) linking such diverse countries as Germany, Egypt, Bosnia and United States or Venezuela, Germany, Spain and Denmark, or Grenada, Jamaica, Canada, and United Kingdom. All interviewees are fluent in two or more languages, some also in Croatian.

Except for the youngest one, who has been involved in long-distance studying in England, all have tertiary education (college or university degree): in business administration, management, marketing, (computer) engineering, information 
technology, graphic design, social media. They originate from middle or upper middle classes; prior to relocation some were corporate executives in transnational firms, some renowned public figures in their countries of origin (e.g. successful Formula 1 drivers, spouse of Miss of Sri Lanka), some had a flourishing business in their countries of origin or made a name for themselves in the documentary film industry.

To sum up, the interviewees are cosmopolitan individuals. Their lives and identities are the product of a complex series of "social structures and processes" involving race, ethnicity, gender and class, as argued by an intersectional approach to migration (Anthias 2012: 106). Their specific intersectionality is further defined by education (may not overlap with class), age (or stage of life-cycle), national citizenship (may not overlap with ethnicity), multi-cultural background and past migration experiences and aspirations, all of which position them in middle or upper middle class ranges of relatively young, well-educated, globally mobile but not necessarily affluent people. How is this positionality transferred to the concrete migration destination - the city of Zagreb - is discussed in the next section.

\section{Immigrants' skills and agency in the city}

These migrants bring substantial human (education, skills, creativity, languages), social (transnational networks) and some of them also economic (financial) capital that they invest in business ventures locally (restaurants, manufacturing) or internationally (design, programming, film production). With their skills, they cover quite a wide spectrum of economic possibilities, and aspire to use them well, not only for their own benefit, but also for the benefit of society: "I wanted to bring change as much as I could", said a talented application developer from Venezuela reflecting on his five-year long residence in Zagreb. Indeed, the intent to be agents of change in the modernising city is shared by a number of migrants and is not just paying lip service. One should not understand it (only) as a business-oriented goal in the service of own benefit, but (also) as a sincere striving for change in areas that they judge need transformation. ${ }^{6}$

Agency is expressed in various ways, depending on an individual's skills and areas of activity: some want to teach locals how to do business, some to contribute to social causes and the visibility of the city's minorities by inviting them to visit their catering establishment, some migrants promote (restaurant) management skills, professional work ethics and provide for the continuous education of restaurant personnel beyond the basics, some engage in marketing the city or other areas of the country via video production, some are into developing applications for various services in the city.

That there is a genuine interest in the society and its issues is indicated by the following: some are able to comment on social conflicts over divisive historical interpretations, discuss gender relations, regionalism and identity issues at length, some are even aware of long-standing disputes over Croatian grammar (sic!). 
Some migrants have become so engaged with the society that they share common concerns with Croatian citizens, debating high taxes and legal insecurity (ascribed to constantly changing laws), the inability of the state to encourage creativity and alike.

Those with catering establishments are engaged in changing the city in a visible way. The Sri Lankan and the Ukrainian entrepreneurs have filled in a genuine gap in the city's food market: with ethnic-type restaurants. ${ }^{7}$ The former positioned themselves in the deficient street food sector, while the latter opted for an international (cosmopolitan)-style place for (upper) middle class clientele. "Be different" encapsulates their beliefs:

"I fell in love with the city. It is very vibrant, full of life. The second thing is, we noticed that some of the other cities we visited in Europe did have food options, but here there is pizza, ćevapi, kebab... How about something different? We thought that if we offered something different, people would be interested, excited."

"Being different" equals opening a "pioneering" type of enterprise, one that does not yet have an established niche. That this would be the best way to go about doing business in Croatia was suggested by a post on FB Internationals living in Croatia, in a discussion that I will comment on extensively below, where one group member recommended to newcomers that "the best business is pioneer business". ${ }^{8}$

Both restaurants are run as a family business, with the owners constantly innovating, studying the market and getting inspiration from the top food cities in the world. Both were opened in quite a short time: the Sri Lankan migrants managed to do it in a week, the reason being that they bought the licence from a successful and well-established restaurant. In the second case, the opening was facilitated by them being incorporated into an existing multifarious domestic enterprise. This is how the migrants escaped the tedious and complicated procedures imposed on foreigners opening a restaurant in Croatia. ${ }^{9}$ Even with this advantage, one of them has stated:

Except for lots of Italian and several Chinese restaurants and one or two Japanese ones, until recently Zagreb had a lack of other world/ethnic food restaurants.

8 Facebook group Internationals living in Croatia, May 21, 2016 (last access 10 October 2016).

9 E.g. one of the more difficult requirements for a foreigner opening a business is that the Foreigners Act (Zakon o strancima) stipulates that for every foreign national, one must employ a certain number of locals, the number increasing with the number of foreigners employed. That particular provision was critically commented by migrants, e.g. "They said that we need to have ten people employed. I said we can't have that many, we don't have that many tables. That will hurt my growth, profits. If I grow, in one year I can give you 20 jobs. But I had no one to explain that to. So we had to employ ten people, otherwise we could not do business and stay in the country" (B., February 2016, excerpt from an interview). 
"It is very difficult to open your own business in Croatia. This is the only thing that I do not like in Croatia. All European countries are very good for business investments. If somebody arrives with money, all of them open the door, except Croatia. Croatia has done everything to make it too difficult."

A migrant, who, together with his brother and partner, has an extensive background in transnational corporate business, added:

"The system does not encourage people like us who are trying to start something. We try so hard to find information: one day at one place you hear one thing, and the next day you hear something different. For a person who doesn't know anybody in this country, trying to find their way around is very hard. There is nobody to talk to, the system does not try to encourage this sort of investment into the country."

This is precisely why two migrants gave up. After encountering too many administrative hurdles to open an itinerant catering business, one person settled for the online sale of men's accessories, while his latest idea to develop an event organization business stopped short of realisation because the person left Zagreb. Rather than opening a tea bar for students, a South African was surviving on family rent and summer jobs. He also left Zagreb, mainly because he was unable to sustain himself on a long-term basis. His reflection about his two-year stay in Zagreb is succinctly expressed in the metaphor opening this chapter. It aptly points out how he felt brought down by a problem-ridden economic system.

My interlocutors with skills in computer engineering, software development and creative industries (graphic design, website building, film making, photography and video) also experience difficulties, in spite of the fact that some are at the forefront of developments in their fields. Unable to break through local monopolies and nepotism in web designing and marketing, a person with an excellent record in this field and the field of documentary production, is struggling and about to look for projects internationally. Another person in the creative industries is not looking for jobs but currently engages in a hobby (creative writing). Those who have international clients have been relatively free from local structural constraints on doing business and are doing well. A migrant from Venezuela complained about the difficulty to force his way with a good idea and the lack of an exciting and inspirational environment and investors:

"Since I am a designer and into technology, while I was living in Copenhagen, I was inspired every day. Culturally speaking, every day I had something new, I had new expositions I could go to. The Danes are first in human-computer interactions, their design is top! From that point of view, which is very personal, I really loved being in Copenhagen. And not only that, but I would come up with a crazy idea that would somehow help the 
life in the city, and then I had to choose who would give me the money. To put that project to run. They would go like - please Mr. Foreigner [...] take our money, take our name, let us go to TV together with this idea. That was for me a bit of a shock here in Croatia! You could have the best idea - and nothing!"

Facebook groups, where advice on available jobs and recommendation about business opportunities are sought for and exchanged, tell a similar, rather bleak story of investment opportunities and success in Croatia, as my interlocutors. On inquiries on how to start an own business as a foreigner, advice given by internationals who have had the experience is discouraging. Opening up with a generalised opinion that it is "a whole other world for doing business" than being a tourist in Croatia because this is "not a very encouraging business environment", a person nailed down a whole set of drawbacks to be encountered by anybody wanting to open a catering outlet: "a boat load of red tape", "inspectors in Croatia are sort of mafia types...", "between the local government and the tax office things are a centuries old, and the old mentality of yesteryear is still very strong", "corruption is rife". ${ }^{10}$

Another person, who had to close down a tea house, had this to say:

"My husband and I tried and failed... Lots of red tape, rules and regulations, very little information, every step you take will require five more - we thought setting up a cafe would be the easiest thing to do, turned out we were wrong." 11

She further commented:

"In our experience, you need to be prepared to knock on many doors, be delayed at every step, get conflicting information from various bureaucrats and also keep paying for everything before you even start, public notaries, accountants, taxes, work permits and various other permits, licences, attests, sanitary books, the list is never ending. If you do everything 'by the book' you won't make any money. [...] [W]e came from the UK feeling very enthusiastic about our new venture and after all the experience we had, we are quite deflated. A lot of time, money, energy wasted. [...] Croatia is a lovely country, people are wonderful and very helpful and we are extremely happy here - just not going to be running a business again - for sure." ${ }^{12}$

The situation in creative industries, another niche occupied by immigrant foreign nationals, is also depicted discouragingly:

10 Facebook group Internationals living in Croatia, May 17, 2016 (last access 10 October 2016).

11 Facebook group Internationals living in Croatia, May 18, 2016 (last access 10 October 2016).

12 See footnote 11 . 
"Well I'm graphic designer with social media degree and branding and visual communication degree and situation for work in creative industry and find a job in general is hard in Croatia! Having lots of degrees is not really a plus here more works contacts and having friends of friends that can help you get a job... Bring a lot of money because take long time get job learn the language know how to work with Croatian people because is hard and confusing to manage them..."13

Advice about starting a project, given by another FB comment, is to make an informed decision based on investigation and have "total determination". This is exactly what the migrants I interviewed have: determination, and it should be added, loads of enthusiasm which transpired through their statements. ${ }^{14}$ In addition, those who wanted to invest in a business locally studied the location and the market since the stakes were high. The Ukrainian couple had made inquiries about the country and where to live before actually moving to Croatia. They contacted ten immigrant families from Russia and Ukraine already living in Croatia for several years and visited them to talk to them about negative and positive aspects of life in Croatia. This lead to the decision to settle and open a restaurant business:

"Everyone has said something like this: the country is ideal for living, ecofriendly, clean, peaceful, safe, air, water, beautiful, wonderful. A bit difficult for business, of course... Everybody told us that they were satisfied. It is not easy, nowhere is it easy, everywhere is difficult... By talking to these people we have seen that it is possible."

\section{Conclusions: locational structural constraints on the transfer of human capital}

This chapter has sought to contribute to a relatively new field of research in "middling" forms of migration (Conradson and Latham 2005) by documenting a group of international highly skilled and well-educated migrants in Zagreb and analysing their agency in the city. The case is doubly interesting: on the one hand, Zagreb and Croatia are not positioned highly on the international immigration and investment map; to put it in Glick Schiller and Çağlar's terminology $(2009,2011)$, Zagreb is not a city whose scale would attract migration. The country and the city offer limited pull factors for transnational and global business. That is why they are only modestly appearing as international migrant destinations, tourist mobilities

13 Facebook group Expats in Zagreb, September 2, 2016 (last access 10 October 2016).

14 Enthusiasm was mainly with respect to what they called "the quality of life" or "the way of life" in Zagreb. This has been analysed in another article (Čapo and Kelemen 2017). 
excluded. On the other hand, and this is linked to the previous point, the specificity of the researched migrants is that most of them had an intimate relationship at the root of migration. Except in two cases, these highly mobile and skilled migrants, with extremely diverse cultural, ethnic and racial characteristics, primarily migrated for family and not for professional reasons and had therefore to find or create their own economic niche in society.

Some have been quite successful in doing so, some less. The successful formula seems to lie in creating opportunities for oneself and opening one's own, not yet carved out niche in the city economy, or, as migrants put it, starting a "pioneer business". The two restaurant ventures described are reaping the benefits of this position, very much like other similar foreign enterprises in the city: the craft beer production pioneered by a Belgian, a Canadian burger place, Argentinian, Korean, Ukrainian, African and French catering outlets or shops, etc. Zagreb, unlike other, much smaller towns in Croatia, has a large and cosmopolitan enough clientele, local and foreign, for these places to do well. With their innovative concepts and ideas, international migrants are acting as agents of change and are participating in restructuring the city, mostly in the domain of catering and services, but also in matters related to management and work ethics. ${ }^{15}$ The extent to which they will also be able to impact the rescaling of the city in global terms - together with local actors and returnees from the diaspora - remains to be seen.

However, there are significant impediments to international migrants' entrepreneurship in the city and the country, no matter how much determination, enthusiasm, skills or good will they have. Locational socioeconomic opportunities, administrative and tax structures, business climate, as well as ways of doing business impact international migrants' efforts at establishing themselves economically. Red tape, nepotism instead of favouring knowledge and competence, lack of competitiveness and support of innovation, administrative hurdles, high taxes and similar are not just anecdotal complaints by international migrants; they are systemic structural problems pinpointed (identified) in World Bank reports and recommendations. ${ }^{16}$ All of them set constraints and limits to the agency of skilled migrants, curtailing the full use of their skills, innovative ideas, entrepreneurship, transnational connections and financial capital.

15 Other international migrants as well as returnees from Croatian diaspora settled on the Adriatic coast are innovating in other domains, mostly in the tourist sector (own unpublished research).

16 The World Bank issues regular reports on the economy in Croatia, the latest was published February 1, 2017: Croatia Policy Notes 2016. Restoring Macroeconomic Stability, Competitiveness and Inclusion, downloaded from: http:/www.worldbank.org/en/country/croatia/publication/restoring-macroeconomic-stability-competitiveness-and-inclusion (last access 18 March 2017). 
The chapter has contributed to theoretical discussions on the ability of migrants (individuals) to act outside of and beyond existing structural contexts and conditions in a locality of settlement. While the issue of individual agency in migration settings has been evaluated in contradictory ways (Korpela 2014), this study unequivocally shows how the agency of transnationally mobile, educated and, prior to their migration to Zagreb, quite successful professionals or entrepreneurs in middle class positions, may be constrained and their complex global positionality (arising from education, skills, global mobility, transnationality, multi-cultural backgrounds, etc.) may become a questionable asset at their new destination, a destination that does not live up to the "scale" of these immigrants. The transfer of their positionality to a new destination - whereby it becomes "translocational positionality" (Anthias 2012) - to a destination which cannot take full advantage of it, may result in leaving the destination for another one. 


\section{REFERENCES}

Amit, Vered, ed. 2007. Going First Class? New Approaches to Privileged Travel and Movement. New York, London: Berghahn Books.

Anthias, Floya. 2012. “Transnational Mobilities, Migration Research and Intersectionality. Towards a Translocational Frame". Nordic Journal of Migration Research 2/2: 102-110.

Bauman, Zygmunt. 2000. Liquid Modernity. Cambridge: Polity Press.

Beaverstock, Jonathan. 2005. "Transnational Elites in the City. British Highly-Skilled Inter-Company Transferees in New York City's Financial District". Journal of Ethnic and Migration Studies 31: 245-268.

Beck, Ulrich and Elisabeth Beck-Gernsheim. 2001. Individualization. Institutionalised Individualism and Its Social and Political Consequences. London: Sage.

Benson, Michaela and Karen O’Reilly. 2009. “Migration and the Search for a Better Way of Life. A Critical Exploration of Lifestyle Migration”. The Sociological Review 57/4: 608-625.

Benson, Michaela and Nick Osbaldiston. 2016. "Towards a Critical Sociology of Lifestyle Migration. Reconceptualizing Migration and the Search for a Better Way of Life". The Sociological Review 64: 407-423.

Božić, Saša, Boško Kuzmanović and Valerija Barada. 2013. "Strani radnici u Hrvatskoj. Porijeklo, status, orijentacije" [Foreign Workers in Croatia. Origin, Status, Orientation]. Migracijske i etničke teme 29/3: 367-404.

Cassarino, Jean-Pierre. 2004. “Theorising Return Migration. The Conceptual Approach to Return Migrants Revisited". International Journal on Multicultural Societies 6/2: 253-279.

Castells, Manuel. 2000. The Rise of the Network Society. Oxford: Blackwell.

Conradson, David and Alan Latham. 2005. "Friendship, Networks and Transnationality in a World City. Antipodean Transmigrants in London". Journal of Ethnic and Migration Studies 31/2: 287-305.

Čapo Žmegač, Jasna. 2005. "Ethnically Privileged Migrants in Their New Homeland”. Journal of Refugee Studies 18/2: 199-215.

Čapo Žmegač, Jasna. 2010. "Return Migration. The Changing Faces and Challenging Facets of a Field of Study”. Ethnologia Balkanica 14: 227-246.

Čapo Žmegač, Jasna, Christian Voß and Klaus Roth, eds. 2010. Co-Ethnic Migrations Compared. Central and Eastern European Contexts. Munich: Otto Sagner Verlag.

Čapo, Jasna. 2012. “'The World Is My Oyster'. Well-Educated Australian-Croatian Citizens in the Era of Global Mobilities”. Croatian Studies Review 8/1: 91-112.

Čapo, Jasna, Caroline Hornstein Tomić and Katica Jurčević, eds. 2014. Didov san. Transgranična iskustva hrvatskih iseljenika [My Grandfather's Dream. Transborder Experiences of Croatian Emigrants]. Zagreb: Institut za etnologiju i folkloristiku, Institut društvenih znanosti Ivo Pilar. 
Čapo, Jasna. 2015. “The Security-Scape and the (In)Visibility of Refugees. Managing Refugee Flow through Croatia". Migracijske i etničke teme 31/3: 387-406.

Čapo, Jasna and Petra Kelemen. 2017. "Zagreb očima međunarodnih migranata. Značenja, potencijali i (re)skaliranje grada" [Zagreb through the Eyes of International Migrants. Meanings, Potentials and (Re)Scaling of the City]. Studia ethnologica Croatica 29/1: 251-277.

Faist, Thomas. 2000. The Volume and Dynamics of International Migration and Transnational Social Spaces. Oxford: Oxford University Press.

Favell, Adrian, Miriam Feldblum and Michael Peter Smith. 2009. "The Human Face of Global Mobility. A Research Agenda". In The Human Face of Global Mobility. International Highly Skilled Migration in Europe, North America and the Asia-Pacific. Michael Peter Smith and Adrian Favell, eds. New Brunswick, London: Transaction Publishers, 1-25.

Fechter, Anne-Meike. 2007. Transnational Lives. Expatriates in Indonesia. London: Routledge.

Giddens, Anthony. 1991. Modernity and Self-Identity. Self and Society in the Late Modern Age. Cambridge: Polity Press.

Glick Schiller, Nina, Linda Basch and Cristina Blanc-Szanton, eds. 1992. Towards a Transnational Perspective on Migration. Race, Class, Ethnicity, and Nationalism Reconsidered. New York: New York Academy of Sciences.

Glick Schiller, Nina and Ayse Çağlar. 2009. "Towards a Comparative Theory of Locality in Migration Studies. Migrant Incorporation and City Scale". Journal of Ethnic and Migration Studies 35: 177-202.

Glick Schiller, Nina and Ayse Çağlar. 2011. Locating Migration. Rescaling Cities and Migrants. Ithaca, NY: Cornell University Press.

Grad Zagreb. Stanovnistvo, kućanstva $i$ stanovi. Popis 2011. [The City of Zagreb. Population, Households and Dwellings. Census 2011]. Zagreb: Gradski ured za strategijsko planiranje i razvoj grada.

Hannam, Kevin, Mimi Sheller and John Urry. 2006. "Editorial. Mobilities, Immobilities and Moorings". Mobilities 1/1: 1-22.

Hoey, Brian A. 2014. "Theorising the 'Fifth Migration' in the United States. Understanding Lifestyle Migration from an Integrated Approach". In The Human Face of Global Mobility. International Highly Skilled Migration in Europe, North America and the Asia-Pacific. Michael Peter Smith and Adrian Favell, eds. New Brunswick, London: Transaction Publishers, 71-92.

Jurković, Rahela and Marijeta Rajković Iveta. 2016. “'Okus doma’. Integracija azilanata protkana transnacionalnim procesima i promicanjem kulinarskih tradicija" ["Taste of Home". Integration of Asylees Intertwined with Transnational Processes and the Promotion of Culinary Traditions]. Studia ethnologia Croatica 28/1: 147-178.

King, Russell, Anastasia Christou and Jill Ahrens. 2011. "'Diverse Mobilities'. SecondGeneration Greek-Germans Engage with the Homeland as Children and as Adults". Mobilities 6/4: 483-501. 
Korpela, Mari. 2014. "Lifestyle of Freedom? Individualism and Lifestyle Migration". In Understanding Lifestyle Migration. Theoretical Approaches to Migration and the Quest for a Better Way of Life. Michaela Benson and Nick Osbaldiston, eds. Basingstoke: Palgrave Macmillan, 27-46.

Kuti, Simona and Saša Božić. 2011. "Analitičke dimenzije za istraživanje transnacionalnih aktivnosti. Primjer kineskih migranata u Hrvatskoj" [Analytical Dimensions for the Research of Transnational Activities. An Example of Chinese Migrants in Croatia]. Revija za sociologiju 41/3: 315-340.

Levitt, Peggy. 2001. Transnational Villagers. Berkeley: University of California Press.

Levitt, Peggy and Nina Glick Schiller. 2004. "Conceptualizing Simultaneity. A Transnational Social Field Perspective on Society". International Migration Review 38/3: 1002-1039.

Mallki, Liisa. 1995. Purity and Exile. Violence, Memory, and National Cosmology among Hutu Refugees in Tanzania. Chicago: University of Chicago Press.

Markowitz, Fran and Anders H. Stefansson, eds. 2004. Homecomings. Unsettling Paths of Return. Lanham MD: Lexington Books.

Meier, Lars. 2015. Migrant Professionals. Local Encounters, Identities and Inequalities. London: Routledge.

Münz, Rainer and Rainer Ohliger. 1997. Deutsche Minderheiten in Ostmittel- und Osteuropa, Aussiedler in Deutschland. Eine Analyse ethnisch privilegierter Migration [German Minorities in Eastcentral and Eastern Europe, Ethnic Germans in Germany. Analysis of an Ethnically Privileged Migration]. Demographie aktuell 9. Berlin: Humboldt-Universität zu Berlin.

Nieswand, Boris. 2016. "Die Dezentrierung der Migrationsforschung” [Decentering Migration Research]. In Migration - Religion - Identität. Aspekte transkultureller Prozesse. Kerstin Kazzazi, Angela Treiber and Tim Wätzold, eds. Wiesbaden: Springer, 283-297.

Nowicka, Magdalena. 2006. Transnational Professionals and Their Cosmopolitan Universes. Frankfurt/Main, New York: Campus-Verlag.

Peračković, Krešimir. 2006. "Sociološki pristup u istraživanju procesa povratnih migracija” [Sociological Approach in the Research of Processes of Returning Migrations]. Društvena istraživanja 15/3: 475-498.

Pozniak, Romana and Duško Petrović. 2014. "Tražitelji azila kao prijetnja” [Asylum Seekers as a Threat]. Studia ethnologica Croatica 26/1: 47-72.

Pries, Ludger. 2001. "The Approach of Transnational Social Spaces. Responding to New Configurations of the Social and the Spatial". In New Transnational Social Spaces. International Migration and Transnational Companies in the Early Twenty-First Century. Ludger Pries, ed. London: Routledge, 3-33.

Sassen, Saskia. 1998. Globalization and Its Discontents. Essays on the New Mobility of People and Money. New York: The New Press.

Sheller, Mimi and John Urry. 2006. "The New Mobilities Paradigm”. Environment and Planning 38: 207-226. 
Smith, Michael P. and Luis Eduardo Guarnizo, eds. 1998. Transnationalism from Below. New Brunswick: Transaction Publishers.

Tsuda, Takeyuki, ed. 2009. Diasporic Homecomings. Ethnic Return Migration in Comparative Perspective. Stanford: Stanford University Press.

"Zakon o strancima" [Foreigners Act]. NN 130/2011. http://narodne-novine.nn.hr/ clanci/sluzbeni/2011_11_130_2600.html. NN 74/2013. http://narodne-novine. nn.hr/clanci/sluzbeni/2013_06_74_1475.html (last access 18 March 2017).

Župarić-Iljić, Drago. 2016. Iseljavanje iz Republike Hrvatske nakon ulaska u Europsku uniju [Emigration from the Republic of Croatia after the Accession to the European Union]. Zagreb: Friedrich-Ebert-Stiftung. 